\title{
Residual Effect of Neem Leaf Extract on The Mortality of Lipaphis erysimi And Its Larvae
}

\author{
Prema Violet Chattree ${ }^{1}$, M.S.Mishra ${ }^{2}$ and A.N.Srivastava ${ }^{1}$ \\ '(Department of Zoology, K.S.SaketP.G.College, Ayodhya, Faizabad (U.P), India) \\ ${ }^{2}$ (Department of Plant Protection, AAI-DU, Allahabad (U.P), India)
}

\begin{abstract}
$\overline{\text { Abstract:The objective was to study the mortality rate of Lipaphis erysimi and its larvae by using neem leaf }}$ extract and appropriate dose of concentrations for checking the insect population.For this cultivars were raised with three dates of sowing at an interval of 15 days each in subplots with three replications each and the clones of mustard aphids were maintained. Theeffect of neem leaf extract on different larvae stages of aphids was studied and for that neem leaf extract of different concentrations was prepared, rearing of aphid's larvae was done and then the mortality rate of the aphid larvae (i.e. $1^{\text {st }}, 3^{\text {rd }}$ and $5^{\text {th }}$ instars) in presence of neem leaf extract at different time intervals with different concentrations $(5 \%, 10 \%, 15 \%, 20 \%)$ was studied.From the study it was observed that the aphid, L. erysimi was killed with the neem leaf extract at all concentrations but there was a significant difference among different concentrations, larval stage and period of treatment. Thus the study showed that by using eco-friendly insecticide, neem leaf extract, the spread of L. erysimi can be controlled which in turn will not hamper the yield of the mustard crop.
\end{abstract}

Keywords: Lipaphis erysimi, neem leaf extract, mortality, eco-friendly, insecticide

\section{Introduction}

The mustard aphid, Lipaphis erysimi, Kaltenbach (Hemiptera: Aphididae) is undoubtedly the most destructive insect pest in India and other tropical and sub-tropical parts of the world [1]. The yield loss of mustard crop caused byL.erysimi is very high in India [2]. The mustard aphid has overcome the barrier of glucosinolates being involved in defense against insects by feeding on the phloem [3], [4] as well as sequestering these compounds and retaining them in the body [5]. Some are metabolized, while others are concentrated in the body for further use [6]. Aphid infestations cause decrease in yield by way of decreasing number of pods per plant, number of grains per pod and oil content of the grains.[7]Chorbandi and Bakhetia, 1987 also reported negative correlation between seed yield and aphids infestation, explaining a decrease of 22 $\mathrm{kg}$. per hectare in yield with an increase of $1 \%$ infestation. They also calculated the economic injury and economic threshold levels as $55-60 \%$ and $40-45 \%$ plants infected by aphids at flowering and bud initiation stages, respectively.

Keeping this in mind a sustainable mustard aphid management program was planned using neem (Azadirachtaindica) belonging to the Meliaceae family, which has been identified as the most promising of all plants for its insect repellent, anti-feedent and medicinal properties by the National Research Council, Washington, USA (1992) and a safe insecticide [8]. It is of botanical origin and easily available to the farmers. The studies conducted by some researchers showed that neem based insecticides provide $95.77 \%$ of L. erysimi mortality as compared to endosulpan with $97.24 \%$. The mustard aphid $L$. erysimi breed parthenogenitically and the female aphid can within 7-10 days give rise to more than 100 nymphs in the same breeding cycle. As a consequence the pest population increases within a very short time to cover the entire flowering shoot and unless there is sustained application of chemical pesticides, several times in cropping season, no crop yield of any extent materializes. Although the application of the pesticide provides temporary relief, such liberal dispersion of the chemicals is costly for the farmers and environmentally hazardous [2].Thus, use of Azadirachtin will be proved to be a good potential inhibitor of the growth of insect cells as compared to other phytochemical pesticides [9], [10], [11].Neem ingredients influences the hormonal system of insects and leads to feeding as well as molting inhibition, retardation of the development and fecundity reduction [12].Based on the above mentioned facts, attempt was made to use neem leaf extract which is most easily available, economically not expensive and has an impact and growth inhibitions towards aphid population.

\subsection{Preparation of different concentrations of Neem leaf extract: \\ II. Materials And Methods}

To study the effect of neem leaf extract on the mortality rate of the mustard aphid ( $L$. erysimi), different concentrations of the extract was prepared [13]. For this leaves of neem were collected from a healthy neem tree in the morning and after collection, they were washed with tap water. These leaves after partial drying were grinded in the grinder for suitable time. These grinded leaves were wrapped in muslin cloth and were 
squeezed till the desirable extract was obtained. The neem leaf extract was collected in four different flasks with different concentration prepared in distilled water viz. 5\%,10\%, 15\% and 20\% and further used to study their effect on the mortality rate of mustard aphid (L. erysimi) [14].

\subsection{Rearing of mustard aphid's larvae:}

To collect and study the different instars of the mustard aphids, they were collected from the plots and brought to the laboratory and reared in environmental chambers at a temperature of $23 \pm 1^{\circ} \mathrm{C}$.Leaves of Brassicanapusand Brassica juncea as food were provided from time to time to the insect till the $5^{\text {th }}$ instar larvae changed into pupal stage. From the pupal stage after sometime emerged the adults. These adults were then released into apparatus prepared for egg laying and these eggs were collected and kept in glass jars for hatching. As the egg hatched and changed into different instars, they were used for the treatments to conduct the different experiments.The mortality percentages in different treatments were recorded in order to find out the toxic effect of the neem leaf extract. The larvae which did not form the pupae and the pupae from which adults did not emerge out to show any response to the treatment were considered as dead.

\subsection{Studying the mortality rate of mustard aphid larvae :}

Petri dishes of $8.5 \mathrm{~cm}$ in diameter were taken and blotting papers of the same size were kept in the petri dishes. Neem leaf extract of different concentrations i.e. $5 \%, 10 \%, 15 \%, 20 \%$ were poured in the petri dishes on blotting paper. Some partially dried food was also kept in the petri dishes to keep the larvae feeding. The petri dishes set as control only had distilled water along with some partially dried food . In every petri dish four larvae of the different instars i.e. $1^{\text {st }}, 3^{\text {rd }}$ and $5^{\text {th }}$ instar were put to see the effect of different concentrations of neem leaf extract on the mortality rate of the mustard aphids for 6 hours, 12 hours and 18 hours separately. Each treatment was replicated four times.

\section{$\%$ mortality in test - \% mortality in normal $\times 100$}

\section{$\%$ Net mortality $=$}

\section{$100-\%$ mortality in normal}

\subsection{StatisticalAnalysis:}

The data was statistically analyzed and interpreted usingANOVA.

\section{Results And Discussion}

To study the residual efficiency of neem leaf extract formulation as eco-friendly control agent against the mustard aphid(L. erysimi), healthy and fresh leaves were used of neem (Azadirachtaindica) plant for extraction. Distilled water was selected for the preparation of different concentrations of neem leaf extract and four different concentrations viz. 5\%,10\%,15\% and $20 \%$ were used against the $1^{\text {st }}, 3^{\text {rd }}$, and $5^{\text {th }}$ instar larvae stages of L. erysimi for different time intervals viz. 6, 12 and 18 hours in the present study. As a control distilled water was used in place of harmful chemical insecticides to reduce chemical pollution and emphasis on the residual efficiency of neem leaf extract.

The effect of treatment of neem leaf extract was that it killed the larvae at all concentrations and as the concentration was increased, the mortality of mustard aphid also increased. It was reported to be highest in $\mathrm{T}_{4}$ and $\mathrm{T}_{3}$ and more in $\mathrm{T}_{2}$ and $\mathrm{T}_{1}$ as compared to control. The order of mortality recorded was$\mathrm{T}_{0}<\mathrm{T}_{1}<\mathrm{T}_{2}<\mathrm{T}_{3}<\mathrm{T}_{4}$

Table 1: Residual effect of neem leaf extract on different instars $\left(1^{\text {st }}, 3^{\text {rd }}\right.$ and $\left.5^{\text {th }}\right)$ of $L$. erysimi when treated for 6 hours

$1^{\text {st }}$ Instar

\begin{tabular}{|c|c|c|c|c|c|c|c|c|c|c|}
\hline Concentration & \multicolumn{4}{|c|}{ No. of larvae treated } & \multicolumn{4}{|c|}{ No. of larvae dead } & \multirow[t]{2}{*}{$\%$ mortality } & \multirow{2}{*}{$\begin{array}{l}\% \text { net } \\
\text { mortality }\end{array}$} \\
\hline Treatment (T) & $\mathrm{R}_{1}$ & $\mathrm{R}_{2}$ & $\mathrm{R}_{3}$ & $\mathrm{R}_{4}$ & $\mathrm{R}_{5}$ & $\mathrm{R}_{6}$ & $\mathrm{R}_{7}$ & $\mathrm{R}_{8}$ & & \\
\hline $\mathrm{T}_{1} 5 \%$ & 4 & 4 & 4 & 4 & 1 & 1 & 0 & 1 & 18.75 & 7.14 \\
\hline $\mathrm{T}_{2} 10 \%$ & 4 & 4 & 4 & 4 & 1 & 1 & 1 & 1 & 25.00 & 14.28 \\
\hline $\mathrm{T}_{3} 15 \%$ & 4 & 4 & 4 & 4 & 1 & 2 & 1 & 2 & 37.50 & 28.57 \\
\hline $\mathrm{T}_{4} 20 \%$ & 4 & 4 & 4 & 4 & 2 & 2 & 2 & 2 & 50.00 & 42.85 \\
\hline $\mathrm{T}_{0}$ Control & 4 & 4 & 4 & 4 & 0 & 1 & 0 & 1 & 12.50 & 0.00 \\
\hline \multicolumn{11}{|l|}{$3^{\text {rd }}$ Instar } \\
\hline $\mathrm{T}_{1} 5 \%$ & 4 & 4 & 4 & 4 & 1 & 0 & 0 & 1 & 12.5 & 6.66 \\
\hline $\mathrm{T}_{2} 10 \%$ & 4 & 4 & 4 & 4 & 1 & 1 & 1 & 0 & 18.75 & 13.33 \\
\hline $\mathrm{T}_{3} 15 \%$ & 4 & 4 & 4 & 4 & 1 & 1 & 0 & 1 & 18.75 & 13.33 \\
\hline $\mathrm{T}_{4} 20 \%$ & 4 & 4 & 4 & 4 & 1 & 1 & 1 & 1 & 25.00 & 20.00 \\
\hline $\mathrm{T}_{0}$ Control & 4 & 4 & 4 & 4 & 0 & 0 & 1 & 0 & 6.25 & 0.00 \\
\hline
\end{tabular}




\begin{tabular}{|l|l|l|l|l|l|l|l|l|l|l|}
\hline $\mathrm{T}_{1} 5 \%$ & 4 & 4 & 4 & 4 & 0 & 0 & 1 & 1 & 12.50 & 6.66 \\
\hline $\mathrm{T}_{2} 10 \%$ & 4 & 4 & 4 & 4 & 0 & 1 & 0 & 1 & 12.50 & 6.66 \\
\hline $\mathrm{T}_{3} 15 \%$ & 4 & 4 & 4 & 4 & 1 & 1 & 0 & 1 & 18.75 & 13.33 \\
\hline $\mathrm{T}_{4} 20 \%$ & 4 & 4 & 4 & 4 & 1 & 0 & 1 & 1 & 18.75 & 13.33 \\
\hline $\mathrm{T}_{0}$ Control & 4 & 4 & 4 & 4 & 0 & 0 & 1 & 0 & 6.25 & 0.00 \\
\hline
\end{tabular}

The effect of different concentrations on the instar was that the mortality rate of $5^{\text {th }}$ instar larvae was much less as compared to $3^{\text {rd }}$ and $1^{\text {st }}$ instar larvae. Most high effect was observed on $1^{\text {st }}$ instar larvae followed by $3^{\text {rd }}$ and $5^{\text {th }}$ instar respectively. As the larval age was increased, the mortality rate got decreased and the order of mortality rate recorded was $1^{\text {st }}$ instar $>3^{\text {rd }}$ instar $>5^{\text {th }}$ instar. The effect of different time interval was also recorded as highest mortality of aphids in 18 hours treatment followed by 12 hours and 6 hours respectively ( 6 hours $<12$ hours $<18$ hours).The maximum mortality was recorded with $20 \%$ leaf extract in case of $1^{\text {st }}$ instar larvae when treated for 18 hours as $92.85 \%$ ( Table 3 ) and minimum mortality $6.66 \%$ was found in case of $3^{\text {rd }}$ and $5^{\text {th }}$ instar larvae with 5\% neem leaf extract when treated for 6 hours ( Table 1 ).In case of control, maximum mortality $12.5 \%$ was recorded in case of $1^{\text {st }}$ instar larvae of L. erysimi and minimum mortality was recorded as $6.25 \%$ in case of $3^{\text {rd }}$ and $5^{\text {th }}$ instar larvae at all-time intervals.

Table 2:Residual effect of neem leaf extract on different instars $\left(1^{\text {st }}, 3^{\text {rd }}\right.$ and $\left.5^{\text {th }}\right)$ of $L$. erysimi when treated for 12 hours

$1^{\text {st }}$ Instar

\begin{tabular}{|c|c|c|c|c|c|c|c|c|c|c|}
\hline Concentration & \multicolumn{4}{|c|}{ No. of larvae treated } & \multicolumn{4}{|c|}{ No. of larvae dead } & \multirow[t]{2}{*}{$\%$ mortality } & \multirow{2}{*}{$\begin{array}{l}\% \text { net } \\
\text { mortality }\end{array}$} \\
\hline Treatment $(\mathrm{T})$ & $\mathrm{R}_{1}$ & $\mathrm{R}_{2}$ & $\mathrm{R}_{3}$ & $\mathrm{R}_{4}$ & $\mathrm{R}_{1}$ & $\mathrm{R}_{2}$ & $\mathrm{R}_{3}$ & $\mathrm{R}_{4}$ & & \\
\hline $\mathrm{T}_{1} 5 \%$ & 4 & 4 & 4 & 4 & 2 & 2 & 2 & 1 & 43.75 & 35.71 \\
\hline $\mathrm{T}_{2} 10 \%$ & 4 & 4 & 4 & 4 & 2 & 2 & 2 & 2 & 50.00 & 42.85 \\
\hline $\mathrm{T}_{3} 15 \%$ & 4 & 4 & 4 & 4 & 2 & 3 & 3 & 2 & 62.50 & 57.14 \\
\hline $\mathrm{T}_{4} 20 \%$ & 4 & 4 & 4 & 4 & 3 & 2 & 3 & 3 & 68.75 & 64.28 \\
\hline $\mathrm{T}_{0}$ Control & 4 & 4 & 4 & 4 & 0 & 1 & 1 & 0 & 12.50 & 0.00 \\
\hline \multicolumn{11}{|l|}{$3^{\text {rd }}$ Instar } \\
\hline $\mathrm{T}_{1} 5 \%$ & 4 & 4 & 4 & 4 & 0 & 1 & 1 & 1 & 18.75 & 13.33 \\
\hline $\mathrm{T}_{2} 10 \%$ & 4 & 4 & 4 & 4 & 0 & 1 & 1 & 1 & 18.75 & 13.33 \\
\hline $\mathrm{T}_{3} 15 \%$ & 4 & 4 & 4 & 4 & 1 & 1 & 1 & 1 & 25.00 & 20.00 \\
\hline $\mathrm{T}_{4} 20 \%$ & 4 & 4 & 4 & 4 & 1 & 1 & 2 & 1 & 31.25 & 26.66 \\
\hline $\mathrm{T}_{0}$ Control & 4 & 4 & 4 & 4 & 0 & 0 & 1 & 0 & 6.25 & 0.00 \\
\hline \multicolumn{11}{|l|}{$5^{\text {th }}$ Instar } \\
\hline $\mathrm{T}_{1} 5 \%$ & 4 & 4 & 4 & 4 & 0 & 0 & 1 & 1 & 12.50 & 6.66 \\
\hline $\mathrm{T}_{2} 10 \%$ & 4 & 4 & 4 & 4 & 0 & 1 & 1 & 1 & 18.75 & 13.33 \\
\hline $\mathrm{T}_{3} 15 \%$ & 4 & 4 & 4 & 4 & 1 & 1 & 1 & 1 & 25.00 & 20.00 \\
\hline $\mathrm{T}_{4} 20 \%$ & 4 & 4 & 4 & 4 & 1 & 1 & 1 & 2 & 31.25 & 26.66 \\
\hline $\mathrm{T}_{0}$ Control & 4 & 4 & 4 & 4 & 0 & 0 & 1 & 0 & 6.25 & 0.00 \\
\hline
\end{tabular}

Considering the treatment of L. erysimi with neem leaf extract for 6 hours as mentioned in Table 1 with $1^{\text {st }}, 3^{\text {rd }}$ and $5^{\text {th }}$ instar larvae, it was observed that the maximum net mortality $42.85 \%$ was recorded in case of $1^{\text {st }}$ instar larvae when treated with $20 \%$ neem leaf extract and minimum net mortality $6.66 \%$ was recorded in case of $3^{\text {rd }}$ and $5^{\text {th }}$ instar larvae when treated with $5 \%$ of neem leaf extract. Similarly, when all the three larvae instars were treated with different concentrations of neem leaf extract for 12 hours (Table 2), the maximum net mortality was found to be $64.28 \%$ in case of $1^{\text {st }}$ instar when treated with $20 \%$ extract and the minimum net mortality $6.66 \%$ was recorded with the $5^{\text {th }}$ instar larvae when treated with $5 \%$ neem leaf extract [15].

Table 3: Residual effect of neem leaf extract on different instars $\left(1^{\text {st }}, 3^{\text {rd }}\right.$ and $\left.5^{\text {th }}\right)$ of $L$. erysimi when treated for 18 hours

$1^{\text {st }}$ Instar

\begin{tabular}{|c|c|c|c|c|c|c|c|c|c|c|}
\hline \multirow{2}{*}{$\begin{array}{l}\text { Concentration } \\
\text { Treatment (T) }\end{array}$} & \multicolumn{4}{|c|}{ No. of larvae treated } & \multicolumn{4}{|c|}{ No. of larvae dead } & \multirow[t]{2}{*}{$\%$ mortality } & \multirow{2}{*}{$\begin{array}{l}\% \text { net } \\
\text { mortality }\end{array}$} \\
\hline & $\mathrm{R}_{1}$ & $\mathrm{R}_{2}$ & $\mathrm{R}_{3}$ & $\mathrm{R}_{4}$ & $\mathrm{R}_{1}$ & $\mathrm{R}_{2}$ & $\mathrm{R}_{3}$ & $\mathrm{R}_{4}$ & & \\
\hline $\mathrm{T}_{1} 5 \%$ & 4 & 4 & 4 & 4 & 2 & 2 & 2 & 2 & 50.00 & 42.85 \\
\hline $\mathrm{T}_{2} 10 \%$ & 4 & 4 & 4 & 4 & 2 & 2 & 3 & 3 & 62.50 & 57.14 \\
\hline $\mathrm{T}_{3} 15 \%$ & 4 & 4 & 4 & 4 & 3 & 3 & 3 & 4 & 81.25 & 78.57 \\
\hline $\mathrm{T}_{4} 20 \%$ & 4 & 4 & 4 & 4 & 4 & 4 & 4 & 3 & 93.75 & 92.85 \\
\hline $\mathrm{T}_{0}$ Control & 4 & 4 & 4 & 4 & 0 & 1 & 1 & 0 & 12.50 & 0.00 \\
\hline \multicolumn{11}{|l|}{$3^{\text {rd }}$ Instar } \\
\hline $\mathrm{T}_{1} 5 \%$ & 4 & 4 & 4 & 4 & 0 & 1 & 1 & 1 & 18.75 & 13.33 \\
\hline $\mathrm{T}_{2} 10 \%$ & 4 & 4 & 4 & 4 & 1 & 1 & 1 & 1 & 25.00 & 20.00 \\
\hline $\mathrm{T}_{3} 15 \%$ & 4 & 4 & 4 & 4 & 1 & 1 & 2 & 1 & 31.25 & 26.66 \\
\hline $\mathrm{T}_{4} 20 \%$ & 4 & 4 & 4 & 4 & 2 & 2 & 2 & 2 & 50.00 & 46.66 \\
\hline $\mathrm{T}_{0}$ Control & 4 & 4 & 4 & 4 & 0 & 1 & 0 & 0 & 6.25 & 0.00 \\
\hline \multicolumn{11}{|l|}{$5^{\text {th }}$ Instar } \\
\hline $\mathrm{T}_{1} 5 \%$ & 4 & 4 & 4 & 4 & 0 & 1 & 0 & 1 & 12.50 & 6.66 \\
\hline
\end{tabular}


Residual effect of Neem leaf extract on the mortality of Lipaphis erysimi and its larvae

\begin{tabular}{|l|l|l|l|l|l|l|l|l|l|l|}
\hline $\mathrm{T}_{2} 10 \%$ & 4 & 4 & 4 & 4 & 0 & 1 & 1 & 1 & 18.75 & 13.33 \\
\hline $\mathrm{T}_{3} 15 \%$ & 4 & 4 & 4 & 4 & 1 & 1 & 2 & 1 & 31.25 & 26.66 \\
\hline $\mathrm{T}_{4} 20 \%$ & 4 & 4 & 4 & 4 & 1 & 2 & 2 & 1 & 37.50 & 33.33 \\
\hline $\mathrm{T}_{0}$ Control & 4 & 4 & 4 & 4 & 0 & 1 & 0 & 0 & 6.25 & 0.00 \\
\hline
\end{tabular}

Table 4: Net mortality Table of Lipaphis erysimi

\begin{tabular}{|c|c|c|c|c|c|c|c|c|c|c|}
\hline & \multicolumn{3}{|c|}{$1^{\text {st }}$ Instar } & \multicolumn{3}{|c|}{$3^{\text {rd }}$ Instar } & \multicolumn{3}{|c|}{$5^{\text {th }}$ Instar } & \multirow[t]{2}{*}{ Mean } \\
\hline & $\mathrm{h}_{1}$ & $\mathrm{~h}_{2}$ & $\mathrm{~h}_{3}$ & $\mathrm{~h}_{1}$ & $\mathrm{~h}_{2}$ & $\mathrm{~h}_{3}$ & $\mathrm{~h}_{1}$ & $\mathrm{~h}_{2}$ & $\mathrm{~h}_{3}$ & \\
\hline $\mathrm{T}_{0}$ & 0.00 & 0.00 & 0.00 & 0.00 & 0.00 & 0.00 & 0.00 & 0.00 & 0.00 & 0.00 \\
\hline $\mathrm{T}_{1}$ & 7.14 & 35.71 & 42.85 & 6.66 & 13.33 & 13.33 & 6.66 & 6.66 & 6.66 & 15.44 \\
\hline $\mathrm{T}_{2}$ & 14.28 & 42.85 & 57.14 & 13.33 & 13.33 & 20.00 & 6.66 & 13.33 & 13.33 & 21.58 \\
\hline $\mathrm{T}_{3}$ & 28.57 & 57.14 & 78.57 & 13.33 & 20.00 & 26.66 & 13.33 & 20.00 & 26.66 & 31.58 \\
\hline $\mathrm{T}_{4}$ & 42.85 & 64.28 & 92.85 & 20.00 & 26.66 & 46.66 & 13.33 & 26.66 & 33.33 & 40.73 \\
\hline Mean & 18.56 & 39.99 & 54.28 & 10.66 & 14.66 & 21.33 & 7.99 & 13.33 & 15.99 & \\
\hline Mean of instars & \multicolumn{3}{|c|}{112.83} & \multicolumn{3}{|l|}{46.65} & \multicolumn{3}{|l|}{37.31} & \\
\hline Mean for periods & \multicolumn{3}{|c|}{$\mathrm{h}_{1}=37.21$} & \multicolumn{3}{|c|}{$\mathrm{h}_{2}=67.98$} & \multicolumn{3}{|c|}{$\mathrm{h}_{3}=91.6$} & \\
\hline
\end{tabular}

Where, $\mathrm{h}_{1}=6$ hours, $\mathrm{h}_{2}=12$ hours ,

$\mathrm{h}_{3}=18$ hours

$\mathrm{CD}$ at $5 \%$ (Treatment $)=5.34$

$\mathrm{CD}$ at $5 \%$ (Instars) $=4.12$

$\mathrm{CD}$ at $5 \%$ (Periods) $=4.12$

Likewise as presented in Table 3, when the three instar larvae of L. erysimi were treated with different concentrations of neem leaf extract for 18 hours, the maximum net mortality was found to be $92.85 \%$ in case of $1^{\text {st }}$ instar larvae when treated with $20 \%$ neem leaf extract and minimum net mortality was recorded as $6.66 \%$ within $5^{\text {th }}$ instar larvae, when treated with $5 \%$ neem extract solution.Considering the $1^{\text {st }}$ instar larvae of $L$. erysimi when treated at different time intervals i.e. 6 hours, 12 hours and 18 hours, the maximum net mortality $92.85 \%$ was found when treated with $20 \%$ neem leaf extract for 18 hours and the minimum net mortality was noted as $7.14 \%$ when the larvae was treated with 5\% solution of neem leaf extract for 6 hours [16].In the same way, if we consider the $3^{\text {rd }}$ instar larvae of L. erysimi at different time intervals i.e. 6 hours, 12 hours and 18 hours, then the maximum net mortality $46.66 \%$ was found in case of the instar when treated with $20 \%$ solution for 18 hours and minimum net mortality $6.66 \%$ was found to be with $5 \%$ neem leaf extract when treatment was done for 6 hours .In the $5^{\text {th }}$ instar larvae, when it was treated with three periods of time i.e. 6 hours, 12 hours and 18 hours, maximum net mortality $33.33 \%$ was found when the larvae was treated for 18 hours with $20 \%$ neem leaf extract.The minimum net mortality was observed as $6.66 \%$ with $5 \%$ neem leaf extract when treatment was done on larvae for 6 hours .

The data in Table 4 shows that all the concentrations of neem leaf extracts viz. 5\%( $\left.\mathrm{T}_{1}\right), 10 \%\left(\mathrm{~T}_{2}\right)$, $15 \%\left(\mathrm{~T}_{3}\right)$ and $20 \%\left(\mathrm{~T}_{4}\right)$ gave significant mortality as compared to control $\left(\mathrm{T}_{0}\right)$. Thehighest mortality was observed in $20 \%\left(\mathrm{~T}_{4}\right)$,followed by $15 \%, 10 \%$ and $5 \%$. Maximum mortality was recorded in case of $1^{\text {st }}$ instar larvae followed by $3^{\text {rd }}$ and $5^{\text {th }}$ instar larvae. 18 hours $\left(\mathrm{h}_{3}\right)$ gave significantly more mortality percentage followed by 12 hours $\left(\mathrm{h}_{2}\right)$ and 6 hours $\left(\mathrm{h}_{1}\right)$.

Table 5: ANOVA for net mortality

\begin{tabular}{|l|l|l|l|l|l|l|l|}
\hline Source of variation & D & S.S & M.SS & F.cal. & F. tab & \multirow{2}{*}{ Result } \\
\cline { 5 - 7 } & & & & & $5 \%$ & $1 \%$ & \\
\hline Due to conc. & 4 & 8729.52 & 2182.38 & 17.53 & 2.63 & 3.89 & S \\
\hline Due to instars & 2 & 5651.05 & 2825.52 & 22.69 & 3.21 & 5.25 & S \\
\hline Due to period & 2 & 2478.50 & 1939.25 & 15.57 & 3.21 & 5.25 & S \\
\hline Due to error & 36 & 4481.45 & 124.48 & & & & \\
\hline Total & 44 & 21340.52 & & & & & \\
\hline
\end{tabular}

For

Conc.

Instars

Period
SE

2.62

2.03

2.03
$\mathrm{CD}$

5.35

4.12

4.12

From the above obtained results it is inferred that by increasing the concentrations of neem leaf extract and the time period, the mortality of $L$. erysimi ( mustard aphid) can be increased significantly .The studies conducted by [17]showed that neem based insecticides provide $95.77 \%$ of L. erysimi mortality as compared toendosulfan ,an acutely neurotoxicinsecticide to both insects and mammals, including humans $(97.24 \%)$. Based on the experiments conducted and the results analyzed, it can be concluded that use of neem leaf extract on the plant or on the mustard aphid will result in low percentage infestation, lowered mummy weight, low emergence rate of adult of $F_{1}$ and even of $F_{2}[18]$ due to the residual effect of the neem leaf extract.. 


\section{Conclusion}

Lipaphis erysimi (Hemiptera: Aphididae) is definitely the most destructive insect pest of Brassica species in India and other tropical and sub-tropical parts of the world. Aphid infestations cause decrease in yield by way of decreasing number of pods per plant, number of grains per pod and oil content of the grains.To exploit the effects of the leaves of neem tree, the leaf extract was prepared by grinding the leaves and squeezing them through a muslin cloth. Four concentrations of the neem leaf extract prepared in distilled water $(5 \%, 10 \%$, $15 \%, 20 \%)$ and a control with only distilled water were studied on three stages $\left(1^{\text {st }}, 2^{\text {nd }}\right.$ and $\left.5^{\text {th }}\right)$ of larvae instars of $L$. erysimi. From the study it was observed that the aphid, L. erysimi was killed with the neem leaf extract at all concentrations but there was a significant difference among different concentrations, larval stage and period of treatment. The highest mortality $92.85 \%$ was recorded in case of $1^{\text {st }}$ instar larvae at $20 \%$ concentration at 18 hours after treatment and minimum mortality $6.66 \%$ for 6 hours of the $3^{\text {rd }}$ and $5^{\text {th }}$ instar larvae. The control reflected the zero net mortality rate (Table 4 ) of $L$. erysimiin the absence of an insecticide meaning heavy infestation. The findings obtained from the present study suggest that by using the ecofriendly neem leaf extractof $20 \%$ concentration on the Brassica plantsor on the mustard aphid directly at the right time i.e. the $1^{\text {st }}$ larvae instar stage for 18 hours ,the infestation ofBrassica species byL. erysimi can be controlled which in turn will control the damage done to the yield of the crop without being dangerous to the environment like the hazardous, neurotoxic chemical insecticides.

\section{References}

[1]. R.Pandey and N.N.Singh, Effectiveness of bio-control based IPM modules against Lipaphis erysimiKaltenbach (Hemiptera: Aphididae),Journal of Plant Protection Research, 48 (1), 2008,112-116.

[2]. M.A.Hossain, M.K.Maiti, A.Basu, S.Sen, A,K. Ghosh and S.K.Sen, Transgenic expression of Onion leaf lectin gene in Indian mustard offers protection against aphid colonization,Crop Sci., 46, 2006, 2022-2032.

[3]. $\quad$ L.R.Nault and W.E.Styer, Effects of sinigrin on host selection by aphids,Entomol. Exp. Appl., 15, 1972, 423-429.

[4]. B.K.Agarwala, Phenotypic plasticity in aphids (Homoptera: Insecta): Components of variation and causative factors, Current Science, 93 (3), 2007, 308-313.

[5]. M.Bridges,A.M.E.Jones, A.M. Bones, C. Hodgson, R. Cole, E.Bartlet, R.Wallsgrove, V.K.Karapapa, N. Watts and J.T.Rossiter,Spatial organization of the glucosinolate-myrosinase system in Brassica specialist aphids is similar to that of the host plant,Proceedings: Biological Sciences, 269 (1487),2002, 187-191.

[6]. G.S.Dhaliwal, R.S. Gill, V.K.Dilwari and A.K.Dhawan, Management of insect-pest complex of cabbage with neem based insecticides, Ecological Agriculture and Sustainable Development, Vol. II,1998, 306-314.

[7]. $\quad$ S.Chorbandi and N.Bakhetia, Yield losses by turnip aphid,Ind. J. Crop Protect., 9 (10), 1987, 671-679.

[8]. $\quad$ C.M.Ketker, Neem as an ecologically safer potential insecticide for agricultural crops,Changing Villages, 8(1), 1989, 1-10.

[9]. M.S.Chari, G.Ramaprasad, S.Sitaramaiah and P.S.N.Murty, Bio efficacy of neem formulations against Spodopteralitura F. in tobacco nurseries,Botanical pesticides-in-integrated pest management, 18(2), 1993, 145-153.

[10]. J.N.Sachan and S.S.Lal, Role of botanical insecticides in Helicoverpaarmigera management in pulses,Botanical Pesticides in integrated pest management, 5(4),1993, 261-269.

[11]. A.Salehzadeh and R.H.C.Strang, The differential effects of neem terpenoids and some other phytochemicals on insect and mammalian cultured cells, Division of Biochemistry and Molecular Biology, Institute of Biomedical and Life Sciences, University of Glasgow, Glasgow, New York, 2001.

[12]. H.Kleeberg, Some neem extracts - properties and possibilities, Trifolio-M, Sonnenstr.22, 2001, D-35633 Lahnaw, Germany.

[13]. Y.P.Singh, S.Pandey, M.B.Guddewar, A.Shukla and M.L.Saini, Efficacy of some plant extracts against mustard sawfly (A. proxima), Plant Protection Bulletin - Faridabad, 43 (3-4), 1991, 26-30.

[14]. G.T.Gujar and K.N.Mehrotra, Inhibition of growth and development of the tobacco caterpillar SpodopteralituraFarb. due to Azadirachtin and other neem products,Indian Journal of Entomology, 45 (4), 1983, 431-435.

[15]. R.V.S.Rao and K.P.Srivastava, Evaluation of neem formulations against sorghum earheadworm,Neemnews letter, 1 (4), 1984, 37-38.

[16]. D.T.Lowery and M.B.Isman, Antifeedant activity of extracts from neem Azadirachtaindica to strawberry aphid. Chaetoriphonfrgaefolii,Journal of chemical ecology, 19:8,1993, 1761-1773.

[17]. G.S.Dhaliwal, R.S. Gill, V.K.Dilwari and A.K.Dhawan, Management of insect-pest complex of cabbage with neem based insecticides,Ecological Agriculture and Sustainable Development: Vol. II, 1998, 306-314.

[18]. M.Ahmad, H.R.OBiewatsch and T.Basedow, Effects of neem treated aphids as food/hosts on their predators and parasitoids, Journal of Applied Entomology, 127 (8), 2003, 458-464. 